\title{
A CIDADE DE
}

\section{BAURU E A}

ESTRADA DE

FERRO NOROESTE

DO BRASIL:

\author{
COMPARAÇÕES INTERNACIONAIS E A BUSCA PELA \\ VALORIZAÇÃO E REQUALIFICAÇÃO DO PATRIMÔNIO \\ FERROVIÁRIO E INDUSTRIAL NO BRASIL
}

TAÍS SCHIAVON UNIVERSIDADE DE ÉVORA, ÉVORA, PORTUGAL

Arquiteta e urbanista pela Universidade Estadual Paulista Júlio de Mesquita Filho (UNESP, campus Bauru, São Paulo, Brasil). Mestra em História, Gestão e Valorização do Patrimônio Industrial pelo Master Erasmus Mundus TPTI (Techniques, Patrimoine et Territoire de I'Industrie, convênio entre as universidades Paris 1 Panthéon Sorbonne, França; Università Degli Studi di Padova, Itália; Universidade de Évora, Portugal), atualmente cursando doutoramento em Arquitetura pela Universidade de Évora, Portugal ${ }^{1}$

DOI

http://dx.doi.org/10.11606/issn.1980-4466.v0i22p190-219

1. Continuando os estudos desenvolvidos no Brasil pelo Projeto Temático Fapesp, a pesquisa desenvolvida para o master TPTI caracterizou-se pela releitura dos dados coletados préviamente no Brasil e por sua adaptação metodológica aos conceitos de Arqueologia e Patrimônio Industrial realizado a partir da identificação da ferrovia como o elemento propulsor ao processo de desenvolvimento econômico e consequente urbanização da região oeste do estado de São Paulo. O vínculo desta pesquisa com a instituição francesa AHICF permitiu que os conhecimentos em torno do desenvolvimento ferroviário na porção oeste do estado de São Paulo fossem dispersos por novas fronteiras de estudo, permitindo a identificação de semelhanças e distinções referentes à implementação ferroviária e industrial em diferentes contextos. Em sua nova etapa, este estudo busca compreender as estratégias e interferências existentes nos processos internacionais (transcontinentais) envolvendo países europeus e sul-americanos, idealizados a partir da comunicação ferroviária e a navegação do Atlântico. Como esses projetos se articularam e influenciaram o desenho histórico e atual das principais cidades cortadas por estes grandes projetos. 


\section{A CIDADE DE BAURU E A ESTRADA DE FERRO NOROESTE DO BRASIL: COMPARAÇÕES INTERNACIONAIS E A BUSCA PELA VALORIZAÇÃO E REQUALIFICAÇÃO DO PATRIMÔNIO FERROVIÁRIO E INDUSTRIAL NO BRASIL}

TAÍS SCHIAVON

\section{RESUMO}

A construção da Estrada de Ferro Noroeste do Brasil, localizada na região Oeste do Estado de São Paulo, pode ser caracterizada como um exemplo da internacionalização de empresas europeias e brasileiras, a partir de investimentos mistos, nacionais e franco-belgas num território ainda pouco urbanizado, uma vez que a ocupação e o povoamento de cerca de $65 \%$ do território do estado de São Paulo ocorre em parceria com a atuação de companhias de Estrada de Ferro, a partir do avanço da Frente Pioneira. A estratégia inicial da companhia procurava comunicar os estados de São Paulo e Mato Grosso (atualmente Mato Grosso do Sul), entretanto, o projeto sofre frequentes alterações, adquirindo características internacionais que permitiriam a comunicação entre os Oceanos Atlântico e Pacífico. Esta estratégia de internacionalização demonstra a difusão do progresso técnico e científico impulsionado a partir da criação de companhias estradas de ferro no país, um meio de locomoção e transporte de mercadorias capaz de modificar hábitos e fisionomias territoriais. A análise destes e de outros fatos possibilitaram a criação de uma rede de estudos estruturados a partir dos núcleos urbanos inicialmente desenvolvidos pela ferrovia e os impactos decorrentes da transição para o modelo rodoviário de transportes intensificado a partir de 1960 na região. Um cenário dinâmico, capaz de descrever o patrimônio da mobilidade como um museu aberto.

\section{PALAVRAS-CHAVE}

Patrimônio Industrial. Patrimônio ferroviário. Planejamento territorial. Urbanização. Ferrovia. 


\section{THE CITY OF BAURU AND THE NOROESTE DO BRASIL RAILWAY: INTERNATIONAL COMPARISONS AND THE QUESTO TO VALUE E REQUALIFY THE RAILROAD AND INDUSTRIAL HERITAGE IN BRAZIL. \\ TAÍS SCHIAVON}

\section{ABSTRACT}

The construction of the railway Noroeste do Brasil, located in the western portion of São Paulo state, can be considered an example of the internationalization of European and Brazilian companies, made possible by national and French-Belgian investments, in a still little urbanized territory, since $65 \%$ of state's area were urbanized by railroad companies while advancing the "Pioneer Front". The company's initial strategy was to connect the states of São Paulo and Mato Grosso (currently Mato Grosso do Sul), however, the project went through frequent changes and acquired international features that would allow the communication between the Atlantic and Pacific Oceans. This strategy of internationalization demonstrates the diffusion of technical and scientific progress driven by railways in the country, a way of transporting people and goods able to modify territorial habits and structures. Analyzing these and other data enabled the creation of a studies network based on the urban centers developed by the railroad and the impacts of the transition to road transport, which intensified in the region during the 1960s. A dynamic scenario, capable of describing mobility heritage as an open museum.

KEYWORDS

Industrial heritage. Railroad Heritage. Territory planning. Urbanization. 


\section{O CONTEXTO MUNDIAL E A CONFORMAÇÃO NACIONAL}

Por várias vezes o conceito de modernidade foi responsável pela narrativa das transformações urbanas de nossa sociedade. Nesse processo, os meios capazes de promover comunicações e articulações no território foram alvo de avanços técnicos, diretamente refletidos na organização e reorganização do território (ANASTASIADOU, 2011).

Ao passo que a sociedade industrial se caracteriza pelo comportamento tipicamente urbano, seu desenrolar possibilita a constante instauração de padrões de desenvolvimento e organização espacial (CHOAY, 1992, p. 1), ambientes onde as teorias e modelos urbanos desenvolvidos por Haussmann, Cerdà, Sitte, Howard, Le Corbusier e tantos outros, influenciariam a atuação de arquitetos e engenheiros por todo o nascente mundo capitalista.

Considerando o continente europeu como berço de grande parte dessas transformações e dispersão dessas ações por todo o mundo, Caron (1992) analisa a evolução dos transportes terrestres, sobretudo relacionados às articulações francesas entre os séculos XIX e XX, especificando em seu estudo a concorrência entre os diferentes modais e a articulação de eixos internacionais de transporte, antes mesmo do advento das ferrovias. Em seu estudo, constata que a estruturação do sistema ferroviário europeu procurou fazer face a três exigências: responder à procura de transportes entre países ou regiões previamente servidas por estradas ou canais, respeitando desta 
maneira lógicas e estratégias de comunicação preexistentes; agir em áreas onde o desenvolvimento econômico fosse tardio, buscando estimular as atividades locais; em acréscimo ao estabelecimento de trocas entre longas distâncias, permitindo assim a estruturação nacional e a integração do espaço europeu. A análise dos fatos históricos, sobreposta à atual articulação dos transportes terrestres europeus, demonstra a constante evolução de eixos históricos interligada aos novos avanços tecnológicos. Nesse processo de diversificação, o ambiente urbano atua de maneira semelhante, buscando sempre a melhor forma de articulação entre a antiga estruturação, as necessidades do novo modal e as exigências do contexto urbano. A decisão de se construir uma ferrovia, uma rodovia ou um canal era resultado direto do confronto entre sua rentabilidade e utilidade (CARON, 1992), fatores constantemente aliados à sua renovação.

Um processo oposto ao ocorrido no Brasil, país em que a tardia organização política aliada à falta de planejamento teve como resultado uma desarticulada rede de transportes (CALÓGERAS, 1928), acompanhada pelo baixo interesse em sua reestruturação. Grande parte das estratégias nacionais optaram, a partir dos anos 1950, pela substituição gradativa da rede de transportes, adotando como novo 'padrão' o modelo rodoviário (BARAT, 1978).

No Brasil, a crescente necessidade de circulação entre os centros de produção e os mercados de consumo e exportação impulsionou, no início do século XIX, o desenvolvimento de diversos projetos. Em geral, essas estratégias buscaram a atuação de investimentos privados, sendo inicialmente desenvolvidos em torno da criação de caminhos terrestres e fluviais e posteriormente ferroviários, em parceria com a interiorização do território impulsionada pela abertura de novas áreas de plantio e povoamento que, a partir do Rio de Janeiro (capital do Império), seguiriam rumo ao Vale do Paraíba, na divisa entre São Paulo e Minas Gerais. A partir dessa região, os caminhos deveriam buscar os produtos extrativistas, que em geral apresentavam a expansão de suas fronteiras, evidenciando a precariedade de transportes e impulsionando novos projetos.

Nesse contexto de transformações, a ferrovia, primeiro grande eixo de propulsão territorial e articulação industrial, busca inicialmente nas áreas de expansão da produção cafeeira, produtos e pessoas, transferidos entre as novas regiões e o mercado consumidor.

De forma contrária, a grande parte das companhias de estrada de ferro no Brasil que possuíam em torno de seu desenvolvimento a lógica 
da expansão da cultura do café, a estrada de ferro Noroeste do Brasil foi concebida como uma estrada de "penetração" buscando promover a urbanização e o adensamento das novas regiões econômicas, possibilitando a comunicação do território, que em menos de 50 anos demonstraria uma surpreendente transformação de caráter espacial.

(...) Espanta-se o europeu, quando ouve chamar de 'velha' uma cidade como Ribeirão Preto, que não conta três quartos de século (...). Tudo se passa como se este país conhecesse em 75 anos, um século no máximo, o que se levou milênios para fazer na Europa. (MONBEIG, 1998, p. 23)

Pouco a pouco a região abandonou a condição de mata fechada em troca da abertura de fazendas e organizados núcleos urbanos dotados de centros de produção, investimentos e influências nacionais e estrangeiras difundidas sob a forma de equipamentos e conhecimentos técnicos. (SALGUEIRO, 2007)

Esse rápido processo de modernização revela as influências dos grandes centros europeus, em virtude da circulação de ideias e ideais dispersos por técnicos e engenheiros do velho mundo, contratados por companhias para a realização de estudos de viabilização e implantação das chamadas 'obras de arte' ferroviárias e consequente atuação urbana. No oeste paulista, em muitos casos, as novas cidades surgiam com características urbanas presentes nos grandes centros urbanos nacionais e mundiais.

\section{A NOROESTE DO BRASIL E O TERRITÓRIO}

O fim da Guerra do Paraguai, em 1870, reafirmou as necessidades em busca do povoamento e o domínio do território brasileiro, idealizadas a partir da comunicação entre o estado do Mato Grosso (divisa entre países como Paraguai e Bolívia e que atualmente representa o território pertencente ao estado do Mato Grosso do Sul) e o litoral brasileiro. Além das intenções presentes na defesa e prolongamento do território, essa região representava ao território sul-americano, importante área de acesso ao Oceano Atlântico, realizado a partir da navegação da Bacia Cisplatina.

Após vários estudos aproximando técnicos e engenheiros internacionais ao Brasil, como os Planos Rebouças (1874), Bicalho (1881), Ramos de Queiroz (1882) e o Plano da Comissão (189o), o governo brasileiro lançou um decreto concedendo "privilégio, garantia de juros e mais favores para o 
estabelecimento de um sistema de viação geral ligando diversos estados da União à Capital Federal” " (BRASIL, 189o). Esse decreto permitia a criação de um trecho entre Uberaba-MG e Coxim-MT, sendo sua concessão de responsabilidade do Banco União do Estado de São Paulo. A falta de recursos suficientes à construção da companhia é colocada entre as possíveis causas do não cumprimento do decreto.

Em 1904, o Sr. Joaquim Machado de Mello, engenheiro brasileiro renomado na Europa, conseguiu juntar recursos entre banqueiros e investidores franceses e belgas para a construção da recém-criada Companhia de Estradas de Ferro Noroeste, que teve como ponto de partida a cidade de Bauru-SP e seu gerenciamento realizado pelos representantes da Compagnie Géneral de Chemins de Fer et Traveux Publics, uma empresa de capital franco-belga sediada na Bélgica. Recursos incomuns no estado de São Paulo, onde grande parte do financiamento de ferrovias possuía o capital nacional ou inglês. Investimentos franceses eram comuns em estados do sul e nordeste do país.

\footnotetext{
A Estrada de Ferro Noroeste do Brasil tem sua estaca zero na cidade de Bauru, onde se entroncam a 'Paulista' e a 'Sorocabana', a primeira ligando-a a São Paulo através da 'Santos-Jundiaí' (...) e a segunda a Santos (FIGUEIRÊDO, 1950, p. 5, 6)
}

Iniciada em 1905, a construção da ferrovia tinha como ponto final a cidade de Cuiabá; em 1908 o destino foi alterado em um novo decreto, sendo prevista a cidade de Corumbá, na divisa com a Bolívia. A partir dessa conformação, a Noroeste abrigaria na cidade de Bauru um dos mais importantes complexos ferroviários da América Latina.

A alteração do trecho a Corumbá aproximaria o mercado brasileiro à Bolívia, Peru, Chile, Paraguai, Argentina e Uruguai, países atuantes na navegação e comércio da Bacia Cisplatina, oferecendo um maior controle sobre as fronteiras e o aumento da influência política do país no continente sul americano, possibilitando a comunicação dos países de fronteira com o Brasil com o Oceano Atlântico, que, se realizado a partir de ferrovias, seria um meio mais rápido quando comparado à navegação fluvial.

2. Decreto n. 862 de 16 de Outubro de 189o. Disponível em: <http://www2.camara.leg.br/legin/fed/decret/1824-1899/decreto-862-16-outubro-189o-523759-publicacaooriginal-1-pe.html> Acessado em: dez. 2016. 


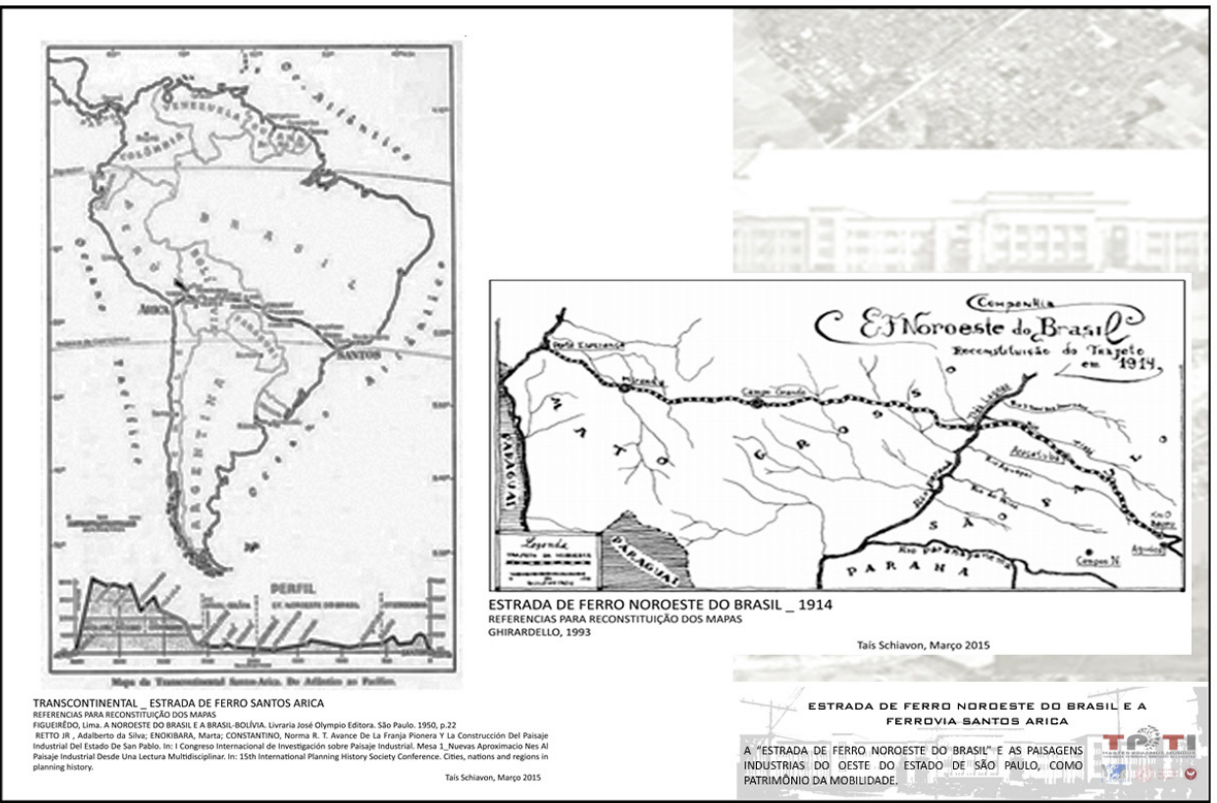

Até o início do século XX o modelo de desenvolvimento ferroviário adotado no país esteve mais próximo ao sistema europeu, onde as companhias atuavam próximas às regiões previamente povoadas e estabelecidas economicamente. Na Europa, a decisão de se construir uma ferrovia, uma rodovia ou um canal era resultado direto do confronto entre sua rentabilidade e utilidade (CARON, 1992), aliadas à sua constante renovação. No Brasil, esse processo avançava à medida que regionalismos agrícolas eram estruturados, permitindo assim a articulação econômica do território. Com o avanço dos trilhos em direção ao "sertão", os investimentos tornaram-se mais raros em relação as regiões já povoadas, como um resultado das incertezas em torno da evolução das companhias em meio aos territórios "desconhecidos e selvagens". (LANGENBUCH, 1971)

Em nenhuma região da America do Sul se operou, pois, na observação exata de Artur Neiva, transformação tão vasta e profunda como a da Noroeste do Brasil e o que era 'selva selvaggia', em 12 anos se transmudou em fazendas, povoações, vilas e cidades modernas. (AZEVEDO, 1950, p. 127, 128) 
Abrindo o sertão, as ferrovias da porção oeste do estado de São Paulo tinham a necessidade de levar consigo os mínimos aparatos à continuidade de seus trilhos e o suprimento das necessidades de seus funcionários. $\mathrm{O}$ forte vínculo existente entre estações ferroviárias e o contexto urbano, ainda em desenvolvimento, revela a dependência do ambiente à dinâmica de sua respectiva companhia ferroviária, características reveladas a partir da análise de diferentes cidades ao longo dos trilhos (SCHIAVON, 2015). Nesse ambiente, as ferrovias constituíram o "elemento técnico predecessor ao estabelecimento da frente pioneira" (GALVÃO, 1996, apud CARVALHO, 2007, p. 44). Ao passo que os trilhos avançavam, cidades surgiam pontilhadas no território, verdadeiros "núcleos motores" responsáveis inicialmente pela ordenação e adensamento do território e posteriormente por seu desenvolvimento econômico. Azevedo (1950, p. 119-120) declara que

(...) a medida que avançava e progredia para o interior, ia a estrada lançando, nas suas estações-fantasmas, as sementes de núcleos urbanos e fazia nascer, na extremidade da linha, essas cidades de vanguarda que se chamavam 'bocas de sertão'. (...) Hoje é o caminho de ferro que funda as cidades e promove, com a industria, as grandes aglomerações urbanas. Ele, o plantador de cidades, é todo-poderoso nessa matéria, como se viu na Noroeste, em que numerosas vilas, hoje cidades de primeira ordem, como que brotaram do chão, na ponta dos trilhos, e pequenas povoações foram obrigadas muito simplesmente a transportar suas casas para onde queria o caminho de ferro. Assim ergueram-se, ao longo da estrada cidades importantes como Lins, Penápolis, Birigui e Araçatuba, e, na variante, Valparaíso, Mirandópolis e Andradina.

\section{INFRAESTRUTURA DO TRECHO}

O modelo homogêneo de expansão, caracterizado pela maior dependência de profissionais em relação às demais regiões exploradas anteriormente, permitiu a consolidação de uma nova área disciplinar e de conformação urbana no estado de São Paulo (MONBEIG, 1998, p. 23). Suas atividades traduziram-se no suporte técnico e teórico para a configuração e reconfiguração do espaço urbano para a difusão da arquitetura 
eclética, para a constituição do repertório paisagístico e para a criação ou remodelação dos antigos largos, praças e jardins (MENEZES, 2008, p. 23). Esse novo ideal urbanizador foi em grande parte impulsionado por companhias de colonização, empreendimentos de capital nacional e internacional responsáveis pelo fracionamento, venda e administração de lotes, atuantes na dispersão da infraestrutura necessária aos novos núcleos abertos ao longo do avanço da frente pioneira. A abertura do sertão gerada a partir do avanço das ferrovias na porção oeste do estado de São Paulo permitiu que, em poucos anos, uma série de equipamentos fossem dispersos por diferentes regiões. Junto a esses novos equipamentos, profissionais atuavam na dispersão dos novos ideais. O engenheiro apareceria substituindo o bandeirante, como o desbravador de áreas desconhecidas e aquele que permitia a ocupação e incorporação destes lugares ao corpo da nação. (CASTRO, 1993, p. 152)

As marcas da Estrada de Ferro Noroeste do Brasil são presentes nas cidades de diversas maneiras. Com as distâncias cada vez maiores entre os centros de produção, mercados de consumo e exportação, e o crescente desenvolvimento de novas cidades abertas pela "Frente Pioneira", evidenciam-se inúmeras carências, atingindo tanto as companhias quanto as estruturas urbanas. Hotéis, escolas, clubes, hospitais, aeroportos entre tantas outras estruturas são instaladas para atendimento dos operários da ferrovia e população urbana em constante crescimento. A parte cultural também se faz marcante, com a instalação de clubes e centros de recreação para a sociedade (SCHIAVON, 2009). Vilas operárias são construídas para abrigo do pessoal. Em algumas cidades estas estruturas se concentravam em um único ponto e em geral eram destinadas apenas aos cargos administrativos da companhia. Porém, em cidades como Bauru, Lins e Araçatuba, que concentravam maior número de equipamentos e pessoal da companhia, as Vilas eram dispersas por diversos pontos da cidade, originando bairros em distintas regiões conforme a dispersão dos equipamentos da companhia em seu contexto urbano. Sendo o maior destaque representado pela conformação existente na cidade de Bauru. 
FIGURA 2

Identificação dos elementos presentes no pátio ferroviário de Bauru e entorno. SCHIAVON, 2015

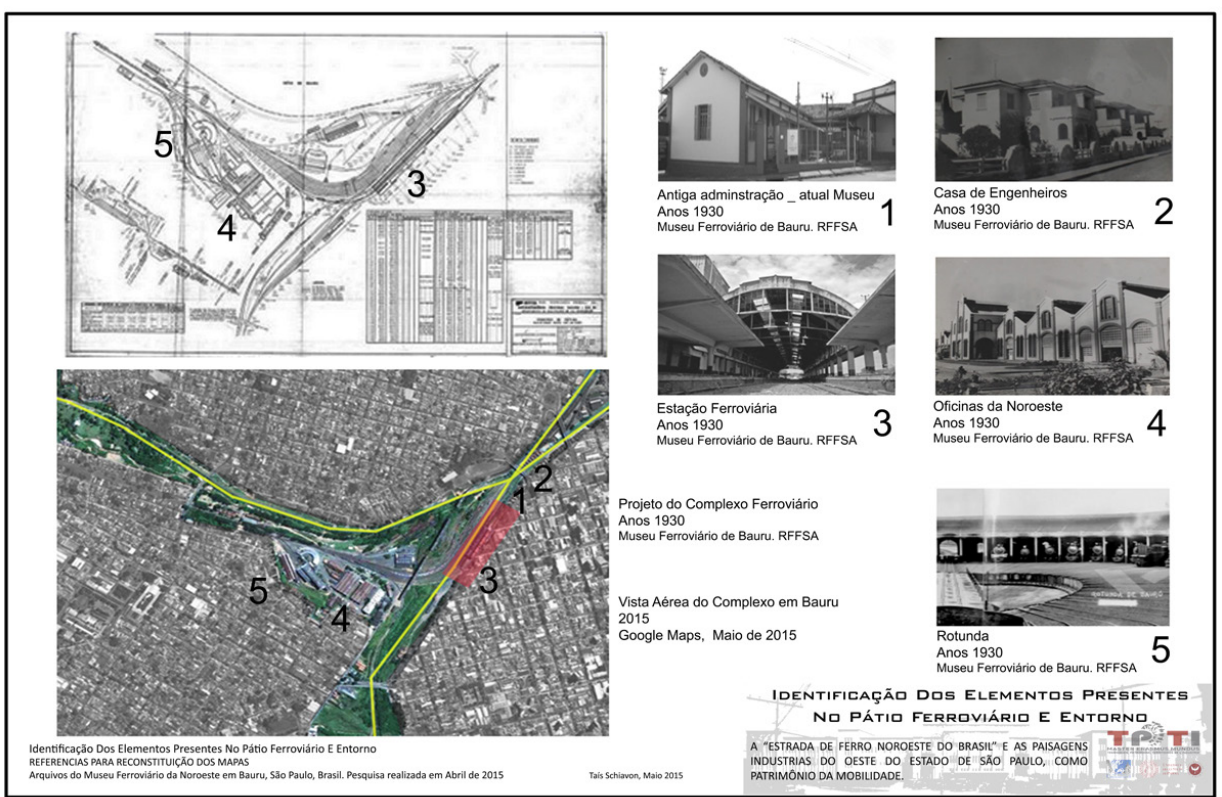

Essa articulação marcará por longo período a implementação e o crescimento de indústrias e a transformação de inúmeras cidades, existindo vários exemplos no próprio estado de São Paulo em que a relação fábricas, habitação operária e ferrovias estrutura vastas zonas. Ademais, muitos complexos ferroviários são verdadeiras usinas, existindo oficinas de produção de componentes, de montagem e de reparos que apresentam uma organização do trabalho e encadeamento de produção de fato industriais. (KÜHL, 1998, p. 40)

\section{BAURU, SEDE DO ENTRONCAMENTO FERROVIÁRIO}

Reconhecido como um dos mais importantes entroncamentos ferroviários no estado de São Paulo, a cidade de Bauru abriga três das maiores ferrovias do estado: Noroeste do Brasil, Alta Sorocabana e Alta Paulista. Ao contrário de grande parte das cidades do oeste do estado de São Paulo, abertas em função do avanço dos trilhos das Companhias de Estradas de Ferro, a cidade de Bauru já apresentava uma organização urbana, conformada por ruas, quadras e pela presença de equipamentos como igreja, praça e cemitério.

(...) o potencial da zona noroeste paulista transformou-se em recurso e energia com o advento da ferrovia, criando e trazendo os meios produtivos requeridos pelo crescimento, formando cidades capazes de 
produzir bens e serviços demandados pelos mercados local, regional, nacional e internacional. Em decorrência, a população e o progresso econômico cresceram. (GALVÃO, 1996, p. 172)

Conforme afirmado por Castro (1993), um novo espírito de desenvolvimento toma conta do antigo vilarejo, fato este consagrado ao observarmos que em menos de 20 anos os trilhos já despontavam a divisa entre os estados de São Paulo e Mato Grosso (atualmente Mato Grosso do Sul).

Se um dos objetivos principais da E. F. Noroeste, alem de seus fins, estratégico e internacional, foi de abrir à civilização e à colonização novas extensões de território e de ligar ao porto de Santos um novo importante centro de produção de café (...). Nessa política de penetração e expansão econômica, de que a Noroeste foi instrumento, o que se realizou parecia um milagre da terra, pela força com que se expandiram e se povoaram pastagens, invernadas e currais e pela rapidez com que se transformavam estações e pequenas zonas agrárias em grandes centros urbanos. (...) como indústria de transporte, puxou a fila das iniciativas e atividades agrícolas, abrindo o caminho a toda a espécie

FIGURA 3

Rua Araujo Leite, fim do século XIX 1893. Destaque para o traçado urbano da cidade com evidência para as ruas Araújo Leite (em laranja) e

$1^{\circ}$ de Agosto (em verde). Estes eixos representavam na época os principais caminhos para as localidades próximas. (SCHIAVON, 2015)

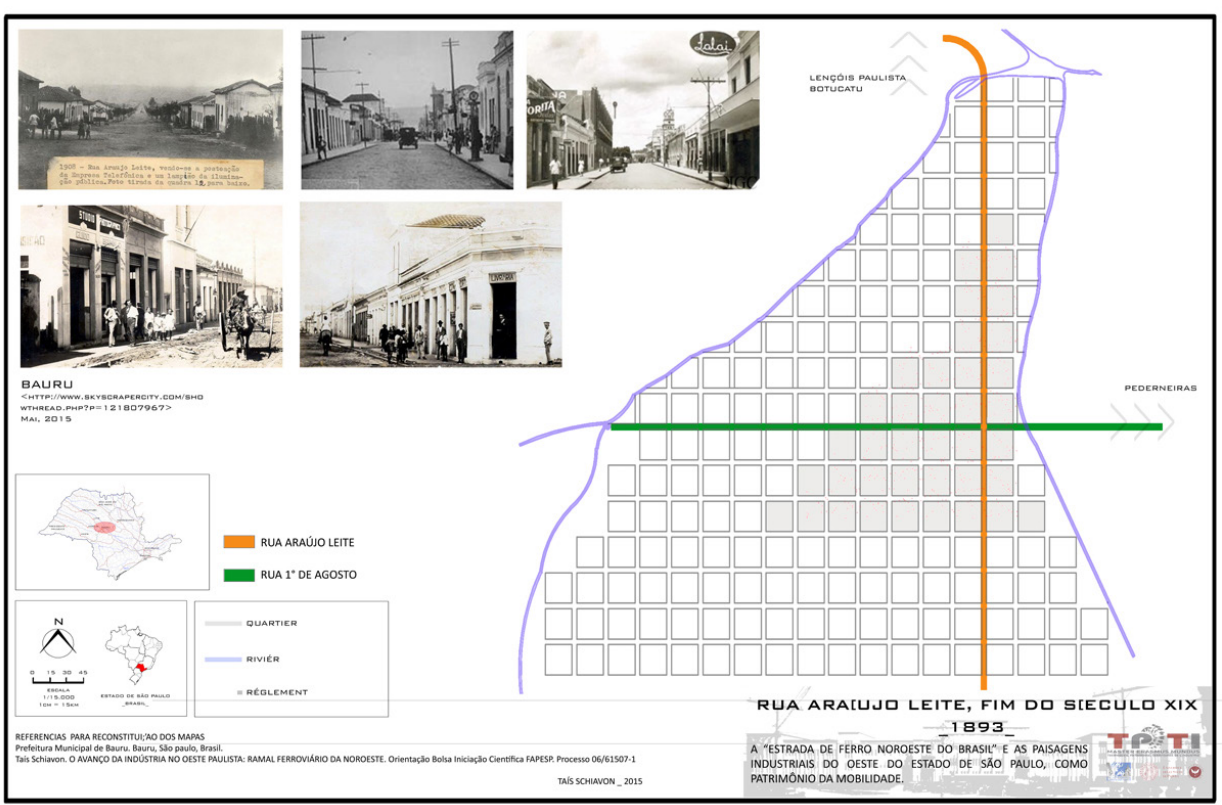


de plantações. A Noroeste era bem a terra da 'Promissão', em que dava tudo, do algodão ao trigo. (AZEVEDO, 1950, p. 124)

As primeiras instalações da companhia foram construídas na porção sul do município, em uma área paralela ao córrego da Água da Ressaca e um pouco atrás do Ribeirão Bauru, aproveitando as áreas planas entre os rios. Para sua instalação, a estrada corta algumas quadras do patrimônio, em uma região até então pouco utilizada, em função de sua localização próxima ao leito do rio, sendo, portanto uma região de interesse secundário ao desenvolvimento da cidade até a instalação da ferrovia. Assim como a Sorocabana, a Noroeste se instala em uma área pouco valorizada da cidade. Das três empresas, a Paulista se instala na área mais 'nobre' e densa do patrimônio original da cidade. Após o término do complexo, a Rua Araújo Leite perdeu seu status econômico para a Avenida Alfredo Maia, que desembocava em frente à estação.

Esta se supõe, é projeto da própria ferrovia, e está dentro de um contexto contemporâneo, de criação de boulevares nas capitais brasileiras, a moda do símbolo máximo europeu, a Paris de Haussmann.

(GHIRARDELLO, 2008, p. 40)

FIGURA 4 Posicionamento das companhias e respectivas estações em Bauru. (SCHIAVON, 2015)

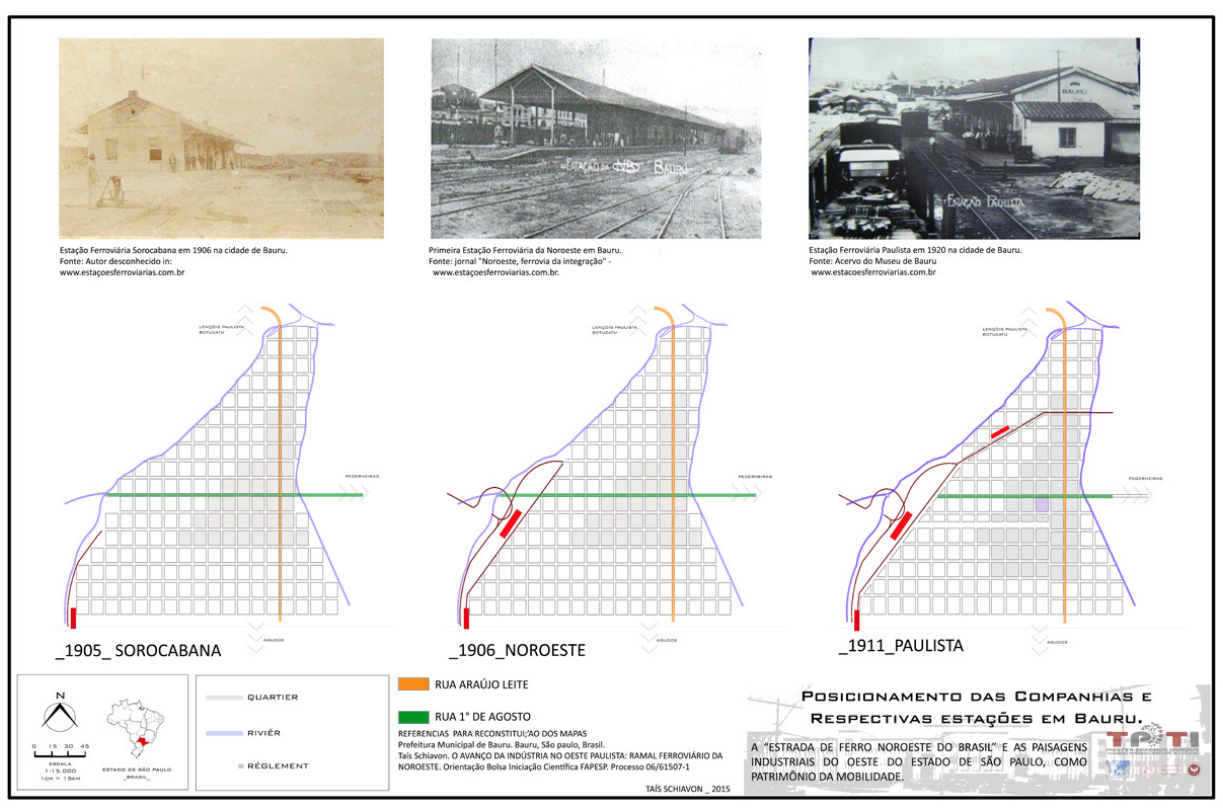




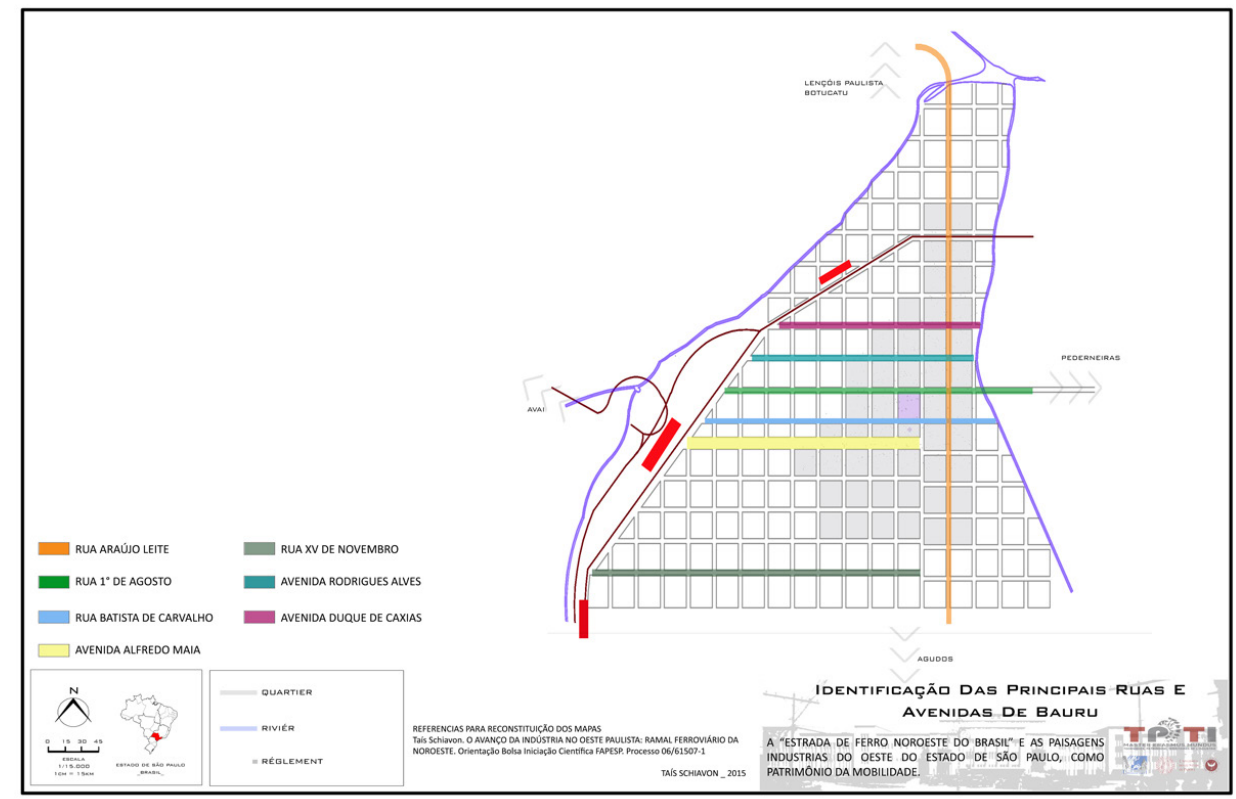

O desenho formado pela junção entre as três companhias aumentou ainda mais a barreira existente entre a porção localizada nas margens do rio e os fundos dos trilhos. Essa região foi ocupada somente anos mais tarde, contendo primeiro características populares, destinadas a operários da companhia e de outras indústrias da região. Os terrenos localizados à frente das companhias caracterizavam-se como os lotes mais valorizados.

Aos poucos os limites da cidade começaram a ser ocupados. Principal "Boca de Sertão" da Linha, ${ }^{3}$ Bauru concentra parte dos principais equipamentos da companhia, responsável por empregar grande parte do operariado da cidade, que formaria principalmente a partir de 1918 bairros operários como a Vila Falcão e a Vila Antártica, além de residências projetadas para funcionários de cargos com maior importância em regiões próximas da estação.

Considerada a capital da zona Noroeste, a cidade de Bauru apresentava já na década de 1920 todos os aspectos característicos de uma

3. Nome que se dava ao último povoado ocupado pelo homem branco, área não isenta de conflitos entre os primeiros povoadores brancos e os últimos remanescentes indígenas. 
grande cidade moderna. Considerando seu posicionamento estratégico em meio a um importante entroncamento ferroviário, apresentava um intenso movimento de hotéis, situados em áreas próximas às estações das companhias, boa iluminação pública, várias linhas de transporte coletivo, hospitais e cinemas, sendo um ativo centro cultural, estendendo, nesse campo, sua influência até Mato Grosso. Relativo à questão econômica, sua forte vocação como entreposto comercial dividia espaço com a atuação de diversas fazendas e indústrias de ampla diversificação. (IBGE, v. XXII, 1956)

A partir dos anos 1940, o desenho urbano, antes ordenado pelo posicionamento das companhias ferroviárias e seus consequentes equipamentos, iniciou sua transição, passando a obedecer ao traçado imposto pelas rodovias, que cada vez mais aproximavam seus trajetos às cidades do oeste do estado. Mais uma vez o posicionamento e a setorização urbana foi traçada a partir de um modal de transportes. Avenidas como a Nuno de Melo, Nações Unidas (e seu prolongamento, Nações Unidas Norte), Rodrigues Alves e Duque de Caxias, passaram a promover a comunicação entre os núcleos mais distantes do município e pontos de comunicação com as rodovias.

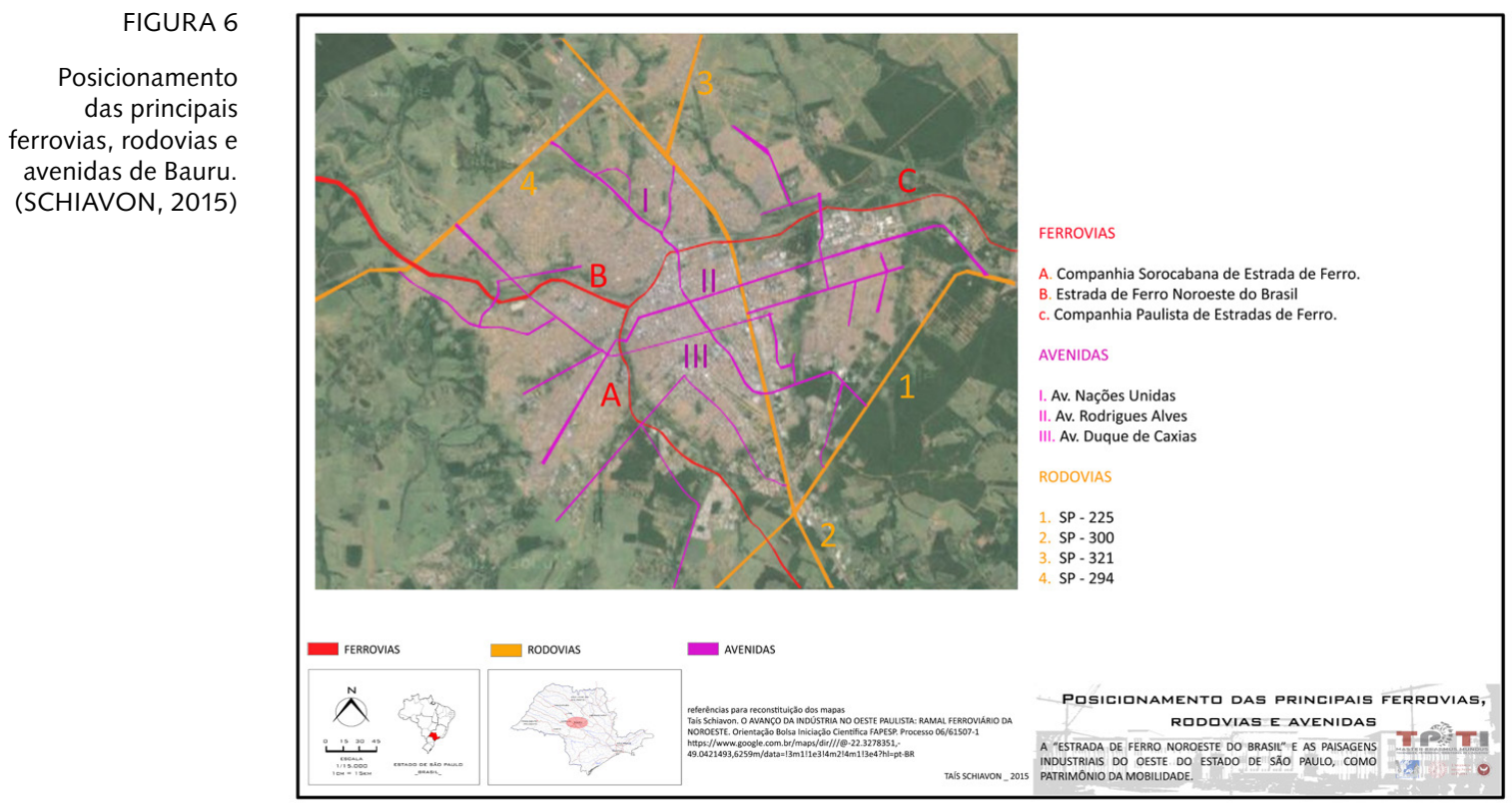


Cem anos após o surgimento das grandes ferrovias paulistas (1870 - 1970) o Brasil consolida a substituição do transporte ferroviário em favor da indústria automobilística como carro chefe do nosso modelo econômico e social. (...) Esta transformação estrutural impacta em cerca de $90 \%$ das cidades paulistas conectadas pelo rosário das ferrovias. Desativados, (...) os pátios, leitos edifícios e bairros ferroviários são como em cadáveres em decomposição nos centros das cidades, (...) decorrente do abandono e descaso das políticas públicas. (BITTENCOURT, 2008, p. 45)

\section{PROGRESSO X TERRITÓRIO}

Em meio à "marcha para o oeste", as companhias Araraquarense, Noroeste, Paulista e Sorocabana promoviam o transporte de pessoas, bens e serviços entre as regiões já urbanizadas e o sertão do oeste do estado, alterando a antiga paisagem do "território desconhecido", para um ambiente composto por cidades "modernas" abertas em um curto período. (RETTO JR; ENOKIBARA. 2012)

O uso do território pode ser verificado através da implantação de infra-estruturas, da dinâmica da economia e da sociedade, das políticas dos governos e das empresas, das normas e leis utilizadas na regulação, das regras de financiamento e da agricultura. (SANTOS; SILVEIRA, 2001 apud VENCOVSKY, 2006, p. 15)

A associação existente entre progresso e ferrovias caracteriza-se como um discurso amplamente utilizado ao longo do século XIX com o intuito de estimular os investimentos neste setor em todo o mundo. O progresso alcançado com os trens ultrapassava o aspecto material, pois as estradas de ferro exerciam influências positivas sobre o conjunto das atividades humanas, alterando costumes, a moral, a cultura, a instrução e a política.

\footnotetext{
4. Marcha para o oeste: nomenclatura utilizada por MONBEIG ao processo de expansão do território brasileiro intensificado no fim do século XIX e início do século XX. O intuito era promover a ocupação além dos limites da Depressão Periférica Paulista, interligando diversos estados brasileiros às regiões mais desenvolvidas e ao Porto de Santos. Compõe tal Marcha os estados de São Paulo, Paraná, Mato Grosso e Minas Gerais.
} 
Esta arquitetura industrial, posta em prática inicialmente nas ferrovias e suas estações, se estenderia a todos os tipos de indústria, expressando uma sociedade inteiramente transformada pelo trabalho. (CHARTON, apud CASTRO, 1993, p. 31)

FIGURA 7

Transposição de barreiras naturais. Destaque para as pontes construídas pela Noroeste. Os primeiros materiais tinham sua origem na Europa, provenientes principalmente da França e Bélgica. Entre as mais importantes, a ponte Francisco de Sá e Barão do Rio Branco.

Essas duas pontes

demonstram também períodos distintos da companhia, a primeira, na divisa entre São Paulo e Mato Grosso, demonstra um período de forte influência técnica e financeira da Europa. Já a segunda, na divisa entre Brasil Bolívia, a hegemonia nacional era marcante, sendo o projeto da ponte símbolo da evolução da engenharia nacional. (SCHIAVON, 2015)

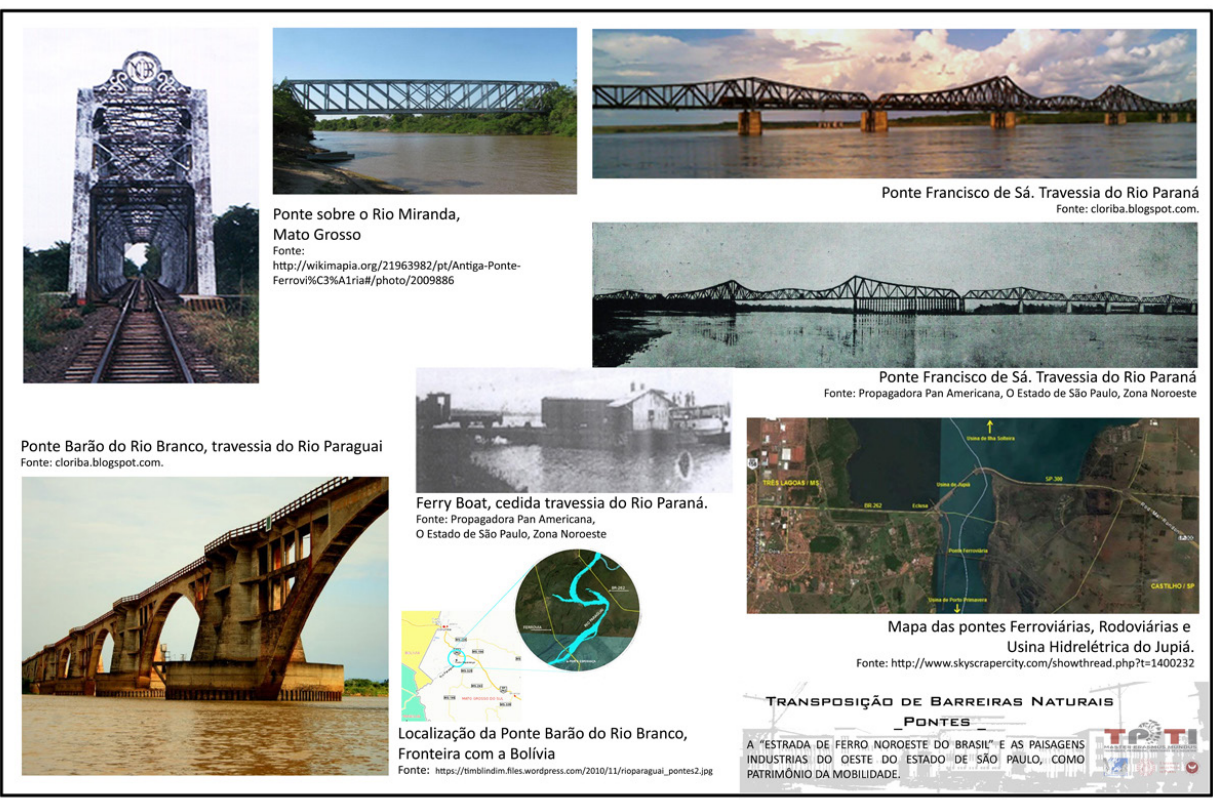

Quanto à Noroeste, uma particularidade pode ser notada: mesmo sendo a gare o principal símbolo de imponência para uma companhia, foi identificado um certo improviso no estabelecimento de estações, característica percebida tanto em Bauru quanto nas demais cidades, onde a ferrovia pode por muitas vezes ser considerada como o elemento pioneiro do município. Em geral, nesse eixo, vagões ou estruturas improvisadas serviam como estações por um longo período. Em Bauru, por muitos anos a companhia fez uso de instalações das demais companhias presentes na cidade, já que no início das atividades grande parte das funções administrativas eram realizadas no Rio de Janeiro e transferidas gradativamente para a cidade. Estruturas de madeira também eram amplamente utilizadas. Essa característica é descrita em vários relatos dos diretores da companhia, que destacavam como maior importância o fator pioneiro do eixo. É de autoria de Eugene Lafón o primeiro projeto para a estação da Noroeste em Bauru, em 1905. Muito próximo do estilo das gares francesas, esse projeto não foi executado, sendo considerado 
desnecessário perante os interesses reais da companhia. Dessa forma, por muitos anos, a Noroeste faz uso de uma estrutura de madeira e das instalações da Sorocabana, outra companhia com sede na cidade de Bauru.

Em 1917, a União encampa por completo a Noroeste. A companhia entregue com o fim do contrato de concessão foi considerada pelo governo como uma estrada inacabada, composta por uma infinidade de pontes de madeira e estruturas ainda a construir, entre elas as importantes pontes sobre os rios Paraná (divisa entre São Paulo e Mato Grosso) e Paraguai (divisa entre Brasil e Bolívia). ${ }^{5}$ Outro projeto para a estação é datado de 1922. Assim como o projeto anterior, não foi colocado em prática, permanecendo em funcionamento as antigas instalações em madeira, substituídas apenas pelo imponente projeto inaugurado em 1939, existente até os dias atuais. No projeto de 1922, o ecletismo representaria a imposição de um estilo arquitetônico capaz de representar uma nação autônoma, composta por profissionais capacitados na execução de projetos e gerenciamento de grandes obras.

5. CEFNOB. Relatório da Diretoria da Companhia de Estrada de Ferro Noroeste do Brasil. Livro Referencia _ RFFSA / R 012 .

FIGURA 8 Projeto para estação de Bauru 1905

In.: Arquivos do Museu Ferroviário da Noroeste em Bauru São Paulo, Brasil. Pesquisa realizada em abril de 2015

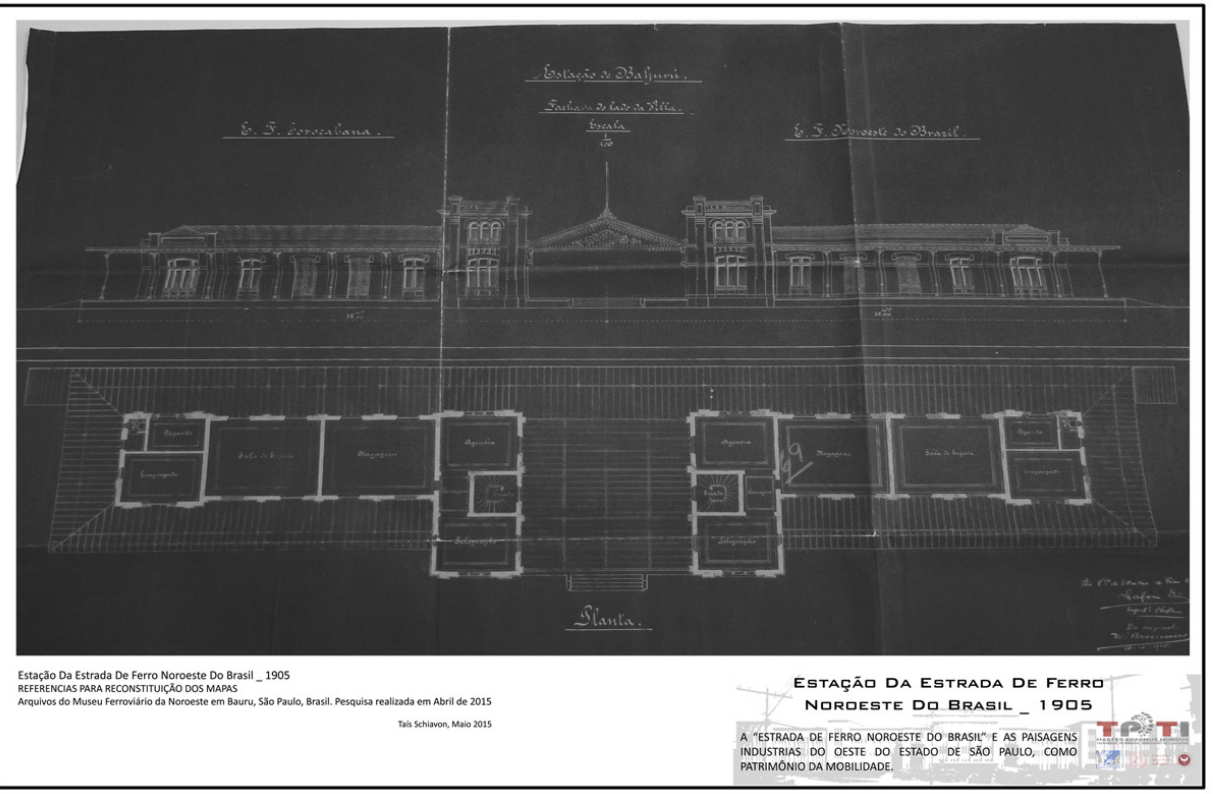


FIGURA 9

Projeto para estação de Bauru de 1922

In.: Arquivos do

Museu Ferroviário da

Noroeste em Bauru

São Paulo, Brasil.

Pesquisa realizada em

abril de 2015
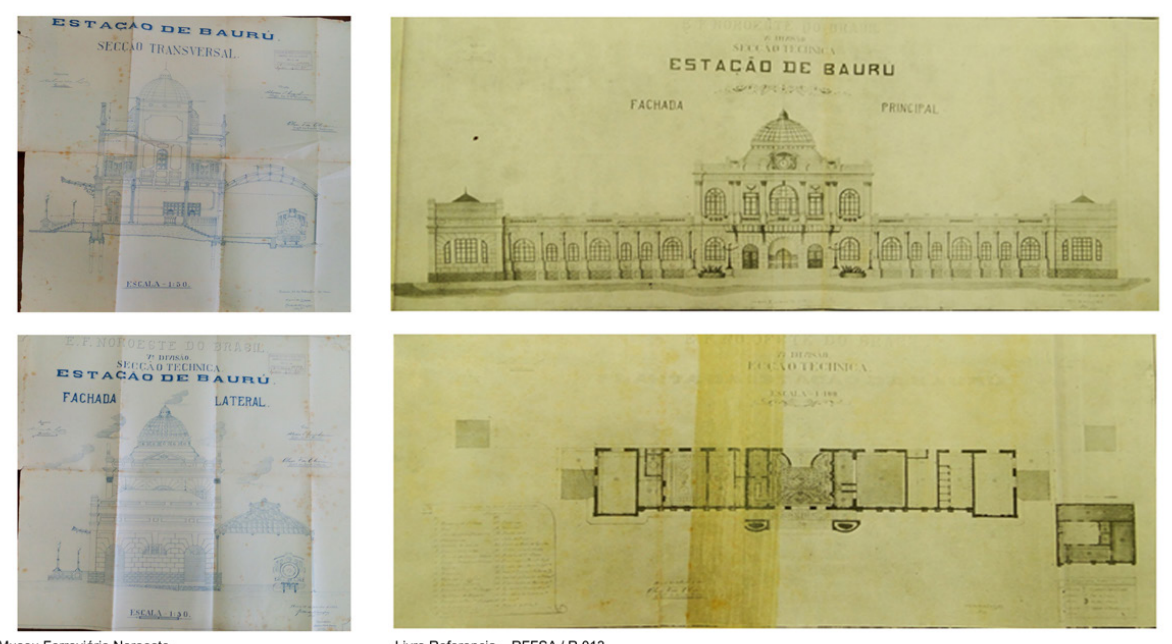

Museu Ferroviário Noroeste

Livro Referencia_RFFSA/R 013

Estaçä́ Da Estrada de Ferró

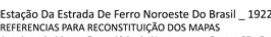

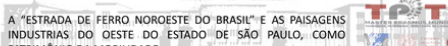

Somente em 1939 a Noroeste inaugurou sua estação, período em que a ferrovia não recebia mais influências estrangeiras. A grandiosa estação apresenta como estilo arquitetônico o art decó, buscando a modernidade a partir da simetria e grandiosidade. Edificada em três andares, o projeto da estação da Noroeste antecipa a utilização do concreto armado como elemento estrutural da gare ${ }^{6}$. Pouco tempo após sua inauguração, o edifício abrigou a sede administrativa das três companhias situadas em Bauru.

As grandes estações das principais cidades apresentavam uma ambivalência refletida no edifício de alvenaria e na cobertura metálica. (...) Nas primeiras décadas deste século, as novas tendências da arquitetura internacional, com o florescimento do racionalismo, avesso à toda

6. Outro projeto símbolo desta técnica no Brasil é representado pela Estação da Central do Brasil (Estrada de Ferro Dom Pedro II), no Rio de Janeiro, inaugurada em 1943. 


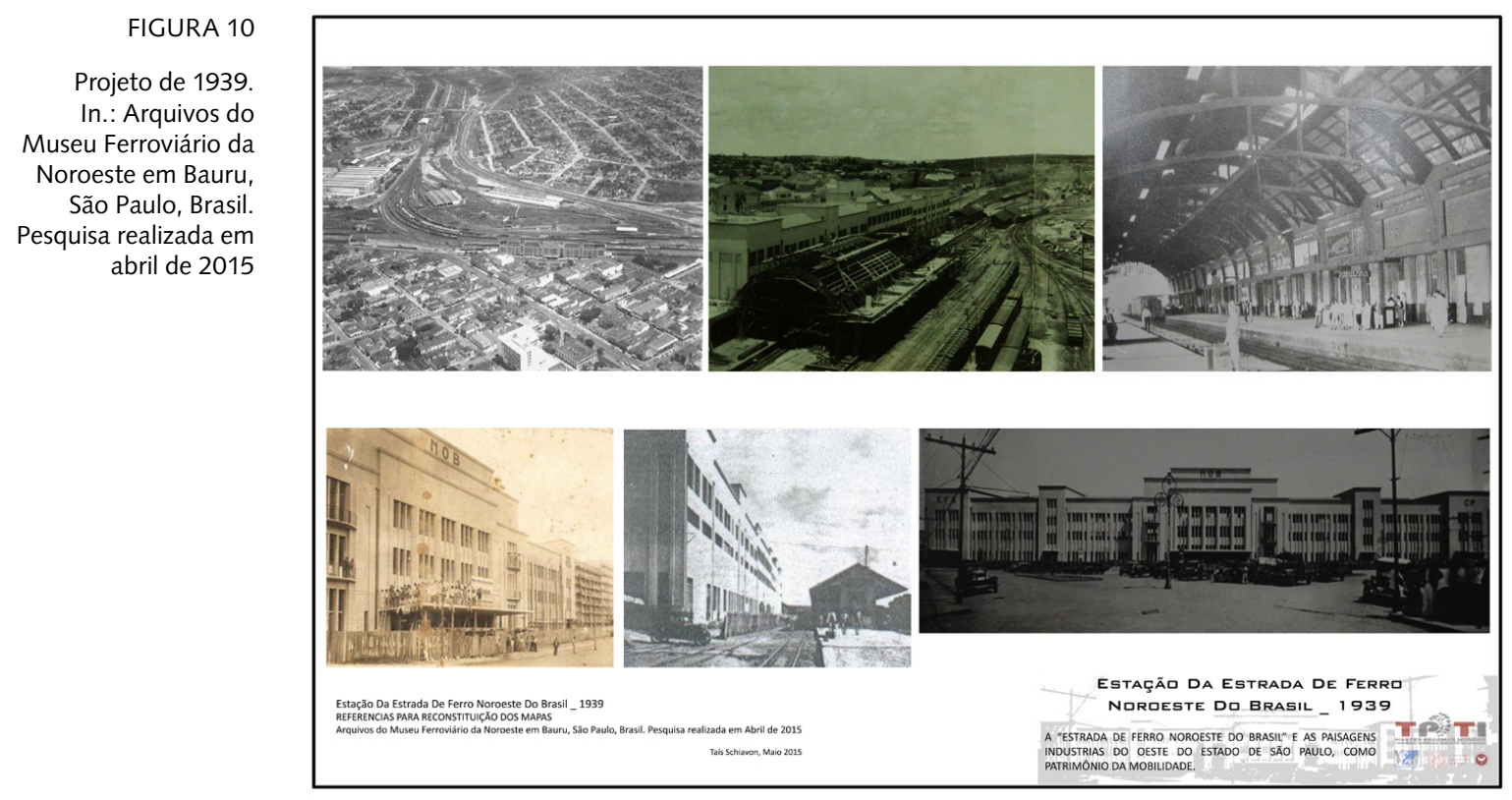

referência histórica, apregoando o uso do concreto armado, levaram a uma tentativa de renovação da linguagem arquitetônica nas ferrovias. (KÜHL, 1998, p. 66)

Importante salientar que o projeto de 1939 evidencia tais transformações identificadas por Kühl, ao propor para a gare uma estrutura em concreto armado, algo novo para o país que até então fazia uso de estruturas metálicas, material proveniente de outros países em grande parte dos casos.

Outro conjunto que merece destaque na cidade de Bauru se caracteriza pelas Oficinas Gerais da Noroeste. Construídas em 1921, representam a importância tanto do desenvolvimento da companhia como da cidade de Bauru, pois demonstram o rápido processo de modernização da principal cidade "Boca de Sertão" da companhia, além da autonomia nacional na gestão do empreendimento, uma vez que caracteriza-se como a primeira grande obra entregue desde a encampação em 1917.

Juntamente à imponência dos edifícios 'industriais' ferroviários, a 'arquitetura industrial' do oeste do estado de São Paulo acompanhou esse processo de modernização. Cada vez mais as cidades passam a apresentar indústrias com maiores índices de sofisticação e capital instalado, crescimento diretamente revestido em sua arquitetura, unidades como Sambra, 
Anderson Clayton, Matarazzo entre outras distribuem modernas unidades fabris por toda a região.

Nos arquivos da companhia, em Bauru, foi encontrado uma espécie de catálogo, contendo detalhes das unidades construídas pela empresa ao longo do avanço de seus trilhos. Moradias coletivas, individuais, hotéis, restaurantes entre outros 'thypos' foram identificados, sendo catalogados conforme a quilometragem da linha.

(...) Numa indústria de transportes, sem perspectivas para suas atividades e ambições profissionais, tem de forçosamente ser mais numerosos (...) a concessão, aos jovens engenheiros que queiram especializar-se, de bolsas e viagens de estudos, para aperfeiçoarem, no estrangeiro, (...) em que se possa formar, com os engenheiros dotados de espírito inventivo, uma equipe de pesquizadores, incumbida, pela via férrea, do estudo e da solução de seus problemas. (AZEVEDO, 1950, p. 272)

Indústria por excelência, a ferrovia abre caminho por onde passa, preparando o terreno para o florescimento de estruturas capazes de agrupar

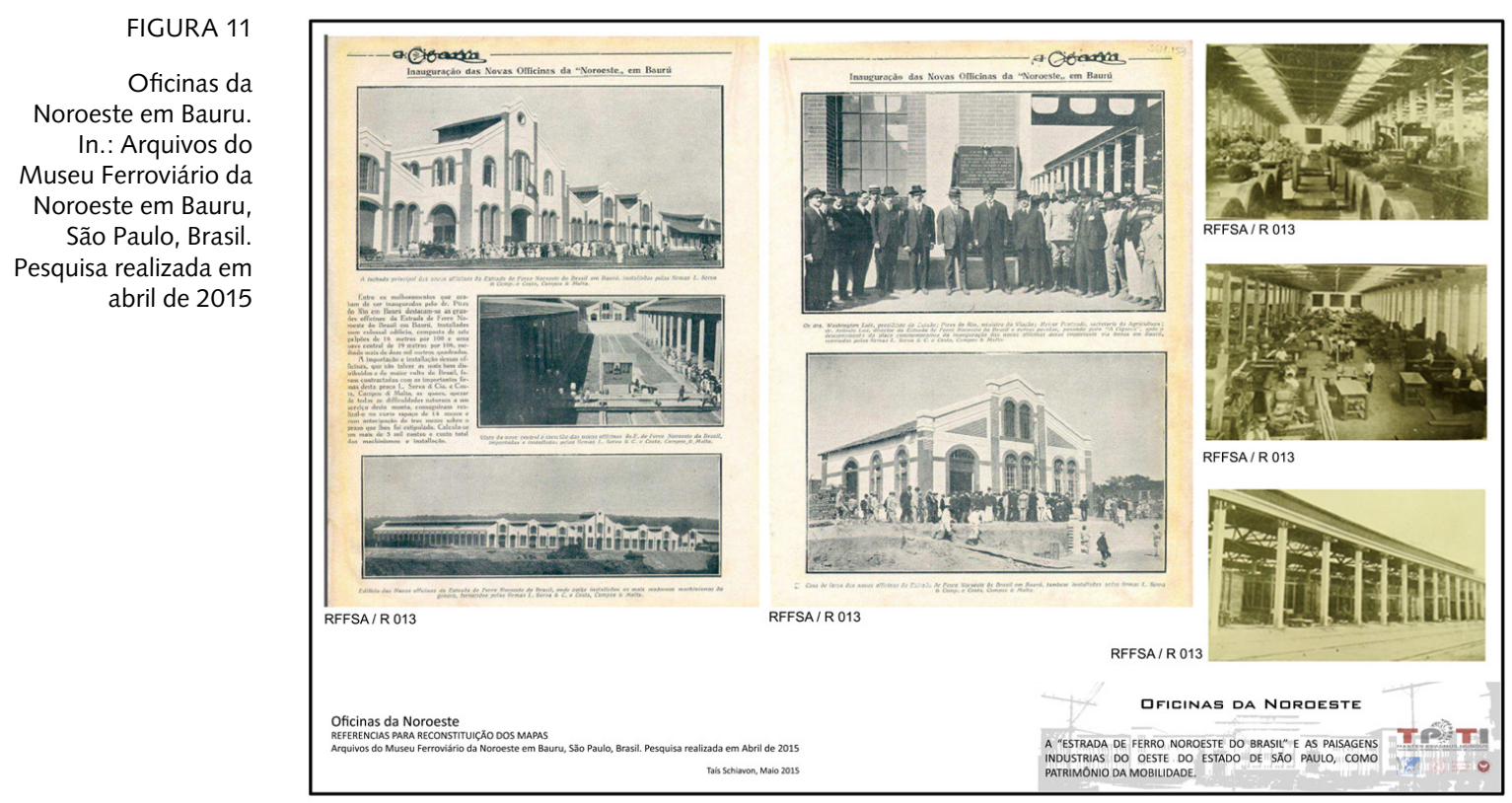


as bases para uma futura organização industrial voltada tanto para atender seu núcleo urbano, quanto para garantir suas necessidades em reparos, novas estruturas e material rodante. Segundo Azevedo (1950, p. 282),

(...) o que uma indústria ferroviária produz, para vender no mercado, é o transporte. (...) Mas a qualidade e a quantidade de serviços que uma via férrea é capaz de prestar à coletividade, (...) dependem, (...) de uma série de fatores entre os quais avultam as condições do respectivo traçado, o seu aparelhamento material, fixo e móvel, a sua organização técnico-administrativa, a natureza e a intensidade de seu tráfego e os recursos que este lhe pode proporcionar.

Patrimônio da mobilidade por excelência, uma indústria ferroviária envolve não apenas suas estações, mas um sistema econômico complexo, envolvendo estruturas urbanas e importantes centralidades formadas em torno da agricultura e da produção industrial, narrando a dispersão de técnicas e conhecimentos capazes de alterar de forma expressiva a organização da paisagem (SCHIAVON, 2016).

\section{A NECESSIDADE DE RECONHECIMENTO}

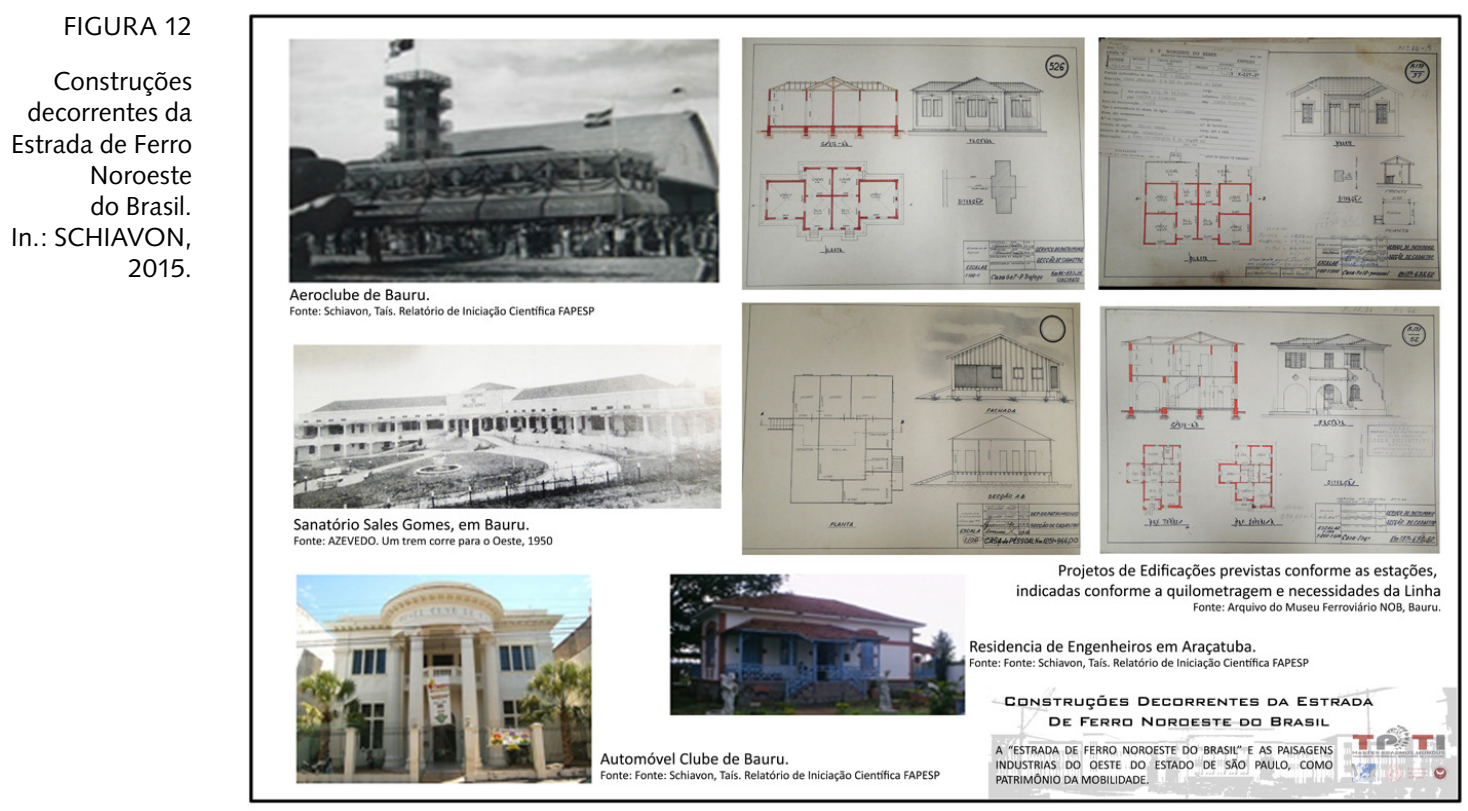


O cenário contemporâneo demonstra em sua formulação os vestígios das diferentes formalizações da atividade humana, reflexos de distintos períodos históricos, agindo como testemunho de avanços e rupturas de antigos padrões de produção e consumo, atuantes em torno da fabricação de objetos cotidianos, produção de energia e suas relações aos contextos urbanos. Um cenário onde a arquitetura busca sobreviver em um mercado ferozmente competitivo. (GRAAFLAND, 2013, p. 305). Os vestígios deste processo evolutivo representam as mudanças ocorridas em meio à sociedade moderna, desvendadas por meio de visões multidisciplinares propostas pelas disciplinas de arqueologia e patrimônio industrial.

Diversas organizações foram articuladas buscando a valorização dos ambientes industriais. Segundo as definições propostas pelo TICCIH, o The International Committee for the Conservation of the Industrial Heritage, organização mundial com filiais em diversos países do mundo, a arqueologia industrial pode ser contextualizada como um método interdisciplinar que estuda todos os vestígios, materiais e imateriais, compreendendo documentos, artefatos, as implantações humanas, paisagens naturais e urbanas, criadas para ou pelos processos industriais, dotados de métodos de investigação adequados ao contexto em questão, buscando a compreensão dos acontecimentos históricos e atuais dos processos de industrialização. Análises que, quando associadas ao patrimônio industrial, possibilitam a compreensão dos vestígios da cultura industrial dotados de valor histórico, tecnológico, social, arquitetônico ou científico, por meio da identificação de edifícios e maquinaria, oficinas, fábricas, minas e locais de tratamento e de refinação, entrepostos e armazéns, centros de produção, transmissão e utilização de energia, meios de transporte e todas as suas estruturas e infraestruturas, assim como os locais onde se desenvolveram atividades sociais relacionadas com a indústria, tais como habitações, locais de culto ou de educação.

A noção de patrimônio em meio ao ambiente industrial surge na segunda metade do século XX na Europa, um momento crucial em que o desaparecimento de ambientes e técnicas industriais de caráter histórico são identificados em decorrência dos diversos conflitos no território europeu, buscando a identificação, valorização e recuperação de ambientes repletos de vestígios produtivos de importância histórica, desprezados por seus traços pouco expressivos quando relacionados às novas técnicas modernas. Assim 
como em grande parte do cenário mundial, no Brasil os anos 1960 representam o abandono de instalações ferroviárias e a substituição de antigos padrões de consumo, ampliando assim sua fragmentação urbana. Condição oposta ao cenário de boa parte do continente europeu, que nesse mesmo período iniciou um longo processo de reestruturação envolvendo políticas locais, regionais, nacionais e internacionais, que se prolongaram até os dias de hoje.

Bons exemplos podem também ser citados no Brasil, ainda escassos quando comparados com o cenário europeu. Em geral as ações se concentram em grandes centros urbanos, quanto às demais cidades, as ações se caracterizam pela baixa articulação entre o contexto urbano e as ações preservacionistas e de requalificação. Merecem destaque o Museu da Língua Portuguesa (estação da antiga São Paulo Railway Company, que infelizmente sofreu um grande incêndio em 2015) e a sede da Orquestra Sinfônica do Estado de São Paulo (na antiga estação Júlio Prestes da Sorocabana), ambientes que em acréscimo à sua função cultural, oferecem também serviços de mobilidade urbana à cidade de São Paulo e sua região metropolitana. $\mathrm{O}$ grande desafio é articular projetos de requalificação em cidades de menor poder aquisitivo. Existem projetos de rearticulação da malha ferroviária do estado de São Paulo, desenvolvidos pela Companhia Paulista de Trens Metropolitanos (CPTM), que buscam a rearticulação de trens de passageiros e ampliação do transporte de mercadorias entre as cidade de São Paulo e Bauru, sede da Noroeste, por exemplo, projetos que infelizmente esbarram em questões burocráticas.

Como comparativo, na França o processo de requalificação de ambientes industriais tem início nos anos 1970, um momento em que pesquisadores, associações, arquitetos e curiosos buscaram em meio ao território os vestígios potenciais de seu patrimônio industrial na tentativa de barrar novas demolições. Em geral, na França, o período marcado entre as transições e intervenções dos monumentos da era industrial sempre foram idealizados em associação à reflexão sobre seus possíveis valores e meios de revitalização. Após esse período de buscas, o trabalho de inventariação acompanhou a investigação de sítios de caráter histórico, buscando atribuir valores culturais aos ambientes remanescentes de períodos de desindustrialização ocorridos após os anos 1970. Os trabalhos foram estruturados buscando a descrição do prestigioso passado do território e sua articulação 
para um progresso eminente. Ações que impulsionam até hoje movimentos em torno da requalificação urbana.

Conforme Pierrot (2014), o histórico de atuações na França engloba de um modo geral três estágios de atuação. O primeiro estágio (1970-1980) foi voltado à recuperação de fábricas desativadas, idealizada a partir da atuação de coletivos / cooperativas em busca de novos investimentos, um processo caracterizado pelo baixo índice de invasão capaz de permitir a manutenção das características do ambiente. Nos anos 1990 o segundo estágio é marcado por demolições, buscando a efetivação de operações privadas em ações destinadas à reconversão de lofts e ateliês para artistas. As maiores intervenções urbanas caracterizaram o terceiro estágio ao longo dos anos 2000, período em que as intervenções são acompanhadas do devido reconhecimento ao valor simbólico do patrimônio industrial. As intervenções deste estágio são caracterizadas por grandes projetos urbanos, elaborados a partir de iniciativas conjuntas entre os setores público e privado.

Entre os exemplos diretamente relacionados ao patrimônio ferroviário, a atuação busca aliar a requalificação de ambientes ferroviários ao transporte, como ocorrido na reestruturação das gares: de l'Est , du Nord e de Lyon, ambientes chave para a mobilidade urbana local, regional e internacional. Ou também como o ocorrido na reconversão da Gare d'Orsay em museu, nos projetos de revitalização do Viaduct des Artes e Parc de Reuilly. Devem ser ressaltadas também as recentes inaugurações da intervenção urbana em Paris Rive Gauche, que transformou um antigo distrito industrial dividido pelos trilhos da Gare d'Austerlitz em um novo bairro integrado e sustentável, envolvendo uma das maiores intervenções urbanas na cidade de Paris desde o século XIX com as propostas de Haussmann.

Recentemente, a cidade lançou uma consulta pública ${ }^{5}$ para que a população opinasse a respeito do futuro da antiga ferrovia da Petite Centuire ${ }^{7}$, uma linha construída no século XIX em torno de uma das antigas muralhas da cidade de Paris. O trecho teve a maior parte de sua linha desativada em 1934, em função de seu ofuscamento pelo desenvolvimento do sistema de metrô, sendo o transporte de mercadorias atuante até 1990. Um espaço

7. Para mais informações, acesse: <http://www.paris.fr/actualites/petite-ceinture-la-reconquete-continue-2265> Acesso em: ago. 2016. 
valioso, compondo uma faixa de 32 quilômetros de terreno 'verde' que se estende por alguns dos bairros mais adensados da capital francesa. A ação busca a identificação da opinião pública para a requalificação do trecho. Ainda em fase inicial, até o momento a ação reabriu como espaço de discussões das propostas a antiga estação Eastern Paris's Ville de Bel-Air. As previsões buscam a gradativa divulgação dos resultados, incluindo até 2017 a abertura de outras nove estações onde a população será incentivada a desenvolver ideias criativas para implementação na antiga linha de trem.

Em uma atitude semelhante, em 2015 o Conselho de Defesa do Patrimônio Histórico, Arqueológico, Artístico e Turístico (Condephaat) lançou no Brasil uma consulta pública buscando a opinião sobre o futuro dos complexos ferroviários da Sorocabana e Noroeste atuantes nas cidades de Sorocaba e Bauru, respectivamente. Ambas as cidades iniciaram o processo de tombamento de seus complexos ferroviários, sendo aprovada até o momento a proposta de preservação e valorização porposta para a Sorocabana; quanto à Noroeste, a decisão ainda aguarda o parecer final.

Importante ressaltar que o primeiro passo foi realizado. Em um contexto marcado por fortes pressões do mercado imobiliário, ações que busquem a opinião pública quanto aos rumos de um ambiente histórico representam um importante avanço ao cenário nacional, propiciando tanto a valorização dos ambientes quanto a identificação dos habitantes em relação ao seu patrimônio.

No Brasil, as ferrovias se revelaram um símbolo de modernidade, que a partir dos anos 1960 entram em confronto direto com as novas dinâmicas de comunicação em suas escalas locais e regionais, nova lógica pautada em torno do modelo automobilístico que impulsionou o desordenado crescimento urbano no país.

\section{ALGUMAS CONSIDERAÇÕES}

Ao considerarmos que, no Brasil, o sistema ferroviário seria ao longo dos anos o precursor para o povoamento do território com a consequente dispersão da 'modernidade', acompanhado pela lógica industrial, podemos afirmar que a sua consolidação possibilitou a definitiva conformação urbana, em sobreposição à antiga lógica rural. A condição moderna imposta pela dispersão de ferrovias no estado de São Paulo pode ser considerada, 
em boa parte de seus domínios, como um fator de extrema importância, uma vez que aproximadamente $65 \%$ do território paulista foi inicialmente atendido pelo sistema ferroviário de transportes mas gradualmente substituído pelo modelo rodoviário. Uma transição que atualmente revela um enorme complexo paisagístico e industrial formulado ao longo da era ferroviária e gradualmente abandonado a partir dos anos 1960, resultado das privatizações e a consequente finalização das atividades de boa parte das companhias, um importante campo de estudos em torno de sua identificação, valorização e reinserção às dinâmicas urbanas.

O modelo rodoviário emitiu uma nova lógica urbana. Nessa transição, as cidades anteriormente servidas pelos trilhos enfrentaram um processo de reestruturação urbana, cujas ações assumem um rítmo variável conforme características locais. Transições claramente visíveis na cidade de Bauru, foco de análise deste artigo, mas que também podem ser vistas em inúmeras cidades ao longo do estado de São Paulo e do país, que em geral demonstram diferentes estágios de preservação de seu patrimônio.

No Brasil, o desafio é fazer com que os projetos de revitalização atinjam os mesmos índices de reaproveitamento e utilização dos grandes centros internacionais, mantendo vivos os registros do desenvolvimento técnico, a continuidade e fluidez urbana, onde "a preservação e a renovação de edifícios, históricos distritos e paisagens afirmam a continuidade e a evolução da sociedade urbana." ${ }^{\prime 8}$ Neste ponto cabem questionamentos buscando a compreensão dos meios de requalificação adotados pelo mundo e os possíveis meios de atuação em cada ambiente no contexto nacional. Ignorada por muitos anos, a arquitetura industrial foi por muitas vezes classificada como simples monumento de nostalgia. Recentemente, esses ambientes adquirem cada vez mais valores históricos atuantes em torno da evolução industrial e suas diferentes formas de atuação, provas vivas do avanço técnico e técnológico da sociedade, narrarando os avanços de seu tempo por meio de sua patrimonialização sendo recentemente alvo de vários os projetos de revitalização.

Mesmo com o aumento do número de estudos, publicações e encontros científicos sobre o tema, as experiências de intervenções nesses bens não

8. <http://www.cnu.org/sites/files/charter_book.pdf> Acesso em: maio 2015. 
ocorre com a mesma frequência e qualidade, evidenciando a necessidade da ampliação do conhecimento do processo de industrialização e identificação de suas atuais potencialidades em meio ao território urbano, transformando os ambientes degradados em potenciais de requalificação.

\section{REFERÊNCIAS}

ANASTASIADOU. Irene. Constructing iron Europe: transnationalism and railways in the interbellum. Technology and European history series. Amsterdan: Amsterdam University Press, 2011.

AZEVEDO, Fernando de. Um trem corre para o oeste: estudo sobre a Noroeste e seu papel no sistema de viação nacional. São Paulo: Martins, 1950.

BARAT, Josef. A evolução dos transportes no Brasil. Rio de Janeiro: IBGE/IPEA, 1978.

BITTENCOURT, Luiz Cláudio. A dimensão urbanística dos leitos, edifícios e pátios ferroviários da cidade de Bauru. In: FONTES, M.; GHIRARDELLO, N. (org.) Olhares sobre Bauru. São Paulo: Unesp; Faac, 2008.

BRASIL. Decreto n. 862, de 16 de outubro de 189o. Coleção de Leis do Brasil, v. X, p.2855, 1890. (Publicação Original) Disponível em: <http://www2.camara.leg.br/legin/fed/decret/1824-1899/ decreto-862-16-outubro-189o-523759-publicacaooriginal-1-pe.html> Acesso em: mai. 2015.

BRESCIANI, Maria Stella Martins. Saberes eruditos e técnicos na configuração e reconfiguração do espaço urbano: estado de São Paulo, séculos XIX e XX. Projeto temático Fapesp nº 05/55338o. Campinas: 2006.

CALÓGERAS, J. Pandiá. Formação histórica do Brasil. Rio de Janeiro: Biblioteca do Exército Editora, 1928.

CANO, Wilson. Raízes da concentração industrial em São Paulo. 2. ed. São Paulo: T. A. Queiroz, 1977.

CARON, François. L'Evolution des transports terrestres en Europe (180o vers 1940). Histoire, économie et société, Paris, v. 11, n. 11, p. 5-11, 1992

CARVALHO, Marina Barroso de. Conformação da estrutura agrária na forma do tecido urbano das cidades do Oeste Paulista: Linha Noroeste. BP.IC. Processo: 06/58402-3. Bauru: 2007.

CASTRO, Maria Ines Malta. O preço do progresso: a construção da estrada de ferro Noroeste do Brasil (1905-1924). Dissertação (Mestrado). Unicamp, Campinas: 1993.

CEFNOB. Relatório da Diretoria da Companhia de Estrada de Ferro Noroeste do Brasil. Livro Referencia: RFFSA / R 012. Bauru: Arquivos do Museu Ferroviário da Noroeste em Bauru.

CHARTON, Edouard. Les chemins de fer. Paris: Librairie de L. Hachette et Cte., 1869.

CHOAY, Françoise. Alegoria do patrimônio. São Paulo: Estação Liberdade, 2001.

CNU. Disponível em: <http://www.cnu.org/sites/files/charter_book.pdf >. Acesso em: mai. 2015. 
GALVÃO, Dora da Silva Ferreira. A expansão geopolítica ferroviária para a região Noroeste do Brasil até a década de 40. Dissertação (Mestrado em Estudos Brasileiros), Universidade Mackenzie. São Paulo, 1996.

GHIRARDELLO, Nilson. Primórdios da formação de Bauru. In: FONTES, M.; GHIRARDELLO, N. (org.) Olhares sobre Bauru. São Paulo: Unesp; Faac, 2008.

GRAAFLAND, Arie. Sobre a criticalidade. In: SYKES, A. Krista (org.). O campo ampliado da arquitetura: antologia teórica 1993-2009. São Paulo: Cosac Naify, 2013.

INSTITUTO BRASILEIRO DE GEOGRAFIA E ESTATÍSTICA, Enciclopédia dos municípios brasileiros. Rio de Janeiro: IBGE, 1956. v. XII.

KÜHL, Beatriz Mugayar. Preservação do patrimônio arquitetônico da industrialização. São Paulo: Ateliê Editorial, 1998.

LANGENBUCH, Jurgen Richard. A estruturação da Grande São Paulo: estudo de geografia urbana. Rio de Janeiro: Instituto Brasileiro de Geografia, Departamento de documentação e de divulgação Geografica e Cartográfica. 1971.

MATOS, Odilon Nogueira de. Café e ferrovias: a evolução ferroviária de São Paulo e o desenvolvimento da cultura cafeeira. São Paulo: Alfa-Omega, 1974. (Biblioteca Alfa-Omega de Ciências Sociais. Série 1.; v. 2)

MENEZES, Everton Pelegrini de. A quadrícula e suas variações na ocupação extensiva do território do Oeste Paulista: estudo comparativo nos quatro ramais ferroviários. BP. IC. Processo: 06/58396-3. Campinas: 2007.

MONBEIG, Pierre. Pioneiros e fazendeiros de São Paulo. 2.ed. São Paulo: Hucitec, 1998.

PARIS. Disponível em: <http://www.paris.fr/actualites/petite-ceinture-la-reconquete-continue-2265>. Acesso em: ago. 2016

PARIS. Disponível em: <http://www.paris.fr/actualites/des-chantiers-participatifs-pour-redonner-vie-a-la-petite-ceinture-3913>. Acesso em: ago. 2016.

PIERROT, Nicolas. La reconversion du patrimoine industriel en Île-de-France. França: Somogy, 2015.

RETTO JR, Adalberto da Silva; ENOKIBARA, Marta. The grid and its variations on the extensive occupation of the West of São Paulo State: a comparative study on the four railroads." 15th International Planning History Society Conference. São Paulo, julho de 2012.

RETTO JR., Adalberto da Silva. Subtema III - saberes urbanos na configuração e re-configuração das cidades formadas com a abertura de zonas pioneiras no oeste do estado de São Paulo. Campinas, 2011.

SALGUEIRO, Heliana Angotti (org). Pierre Monbeig e a geografia humana brasileira. Bauru: EDUSC, 2006.

SANTOS, Milton; SILVEIRA, Maria Laura. O Brasil: território e sociedade no início do século XXI. Rio de Janeiro: Record, 2001.

SCHIAVON, Taís. Heritage of Mobility In Brazil: The Railway "Noroeste do Brasil" and the Industrial Landscapes of the Western Portion of São Paulo State TICCIH Bulletin, n. 72, p. 
10-11, 20 de abr. 2016. Disponível em: < http://ticcih.org/wp-content/uploads/2016/o4/TB72162. pdf $>$. Acesso em: dez. 2016.

SCHIAVON, Taís. Le Chemin de Fer Noroeste do Brasil et les paysages industriels de l'Ouest de l'État de São Paulo, comme patrimoine de la Mobilité au Brésil. Dissertação (Master Techniques, Patrimoine et Territoires de l'Industrie), Universidade de Évora, Évora, Portugal, 2015.

Disponível em: <http://dspace.uevora.pt/rdpc/handle/10174/18401>. Acesso em: jan. 2016.

SCHIAVON, Taís. O avanço da indústria no oeste paulista: ramal ferroviário da Noroeste. BP.IC. Processo 08/61507-1, São Paulo: 2009.

VENCOVSKY, V. P. Sistema ferroviário e o uso do território brasileiro: uma análise do movimento de produtos agrícolas. Dissertação (Mestrado em Geografia), Instituto de Geociências, Universidade Estadual de Campinas, Campinas, 2006.

\section{Artigo recebido em: 19/08/2016}

Artigo aprovado em: 29/11/2016 